\title{
SOCIAL SUPPORT AND SELF-ESTEEM ON TENDENCY OF DEPRESSION IN ADOLESCENT WOMEN
}

\author{
Bayu Sekar Larasati, Hally Weliangan
}

\author{
Bayusekarlarasati30@gmail.com \\ Faculty of Clinical Psychology, \\ University of Gunadarma, \\ Margonda Raya Street No. 100, Depok 16424
}

\begin{abstract}
The phenomenon of teenagers today seems to want to look physically attractive, such as having white skin, smooth faces, and slim bodies. This phenomenon can create pressure for adolescents so that it is possible to tend to depression. Depression can be affected by factors of social support and self-esteem. The method used is quantitative, a sample of 110 girls. The measuring instrument used in this study was adapted from Beck's Depression Inventory, the Multidimensional Scale Of Perceived Social Support, and The Coopersmith Self Esteem Inventory. The results of the study simultaneously showed that there was an effect of social support and self-esteem on the tendency of depression in adolescent girls of $0.000(\mathrm{p} \leq 0.01)$ with an $\mathrm{R}$ Square value of $38.6 \%$. This showed that the hypothesis is accepted is that there is an influence of social support and self-esteem on the tendency of depression in adolescent girls by $38.6 \%$ and $61.4 \%$ influenced by other factors. In addition, the effect of social support on the tendency of depression in adolescent girls has a significant effect of 0.021 $(\mathrm{p} \leq 0.05)$ with an $\mathrm{R}$ Square value of $4.9 \%$. Self-esteem on the tendency of depression in adolescents shows a significant effect of $0.000(\mathrm{p} \leq 0.01)$ with an $\mathrm{R}$ Square of $37.6 \%$.
\end{abstract}

Keywords: Social Support, Self-Esteem, Depression

\section{INTRODUCTION}

According to Sarwono (2013) adolescence is a time full of emotion and sometimes explosive temper that arise because of the conflict of values. In adolescence, there is a process of developmental changes such as biological or physical changes, socioemotional and cognitive (Santrock, 2013). Denich \& Ifdil (2015) also said that physical changes in adolescents cause unwanted psychological impacts so that many adolescents pay more attention to appearance than other aspects of adolescents. Therefore, it is not surprising that adolescences spend a lot of time paying attention to the details of their appearance and are very sensitive to criticism from those around them (Berk, 2003). The current phenomenon, many adolescences think that an attractive appearance is those who have white skin, slim bodies, and smooth faces.

Based on the results of a survey conducted by Anna (Kompas.com, 2018) stating that more than $70 \%$ of women define beauty as the condition of their body and facial skin that looks clean, bright, and shiny, as well as for teenagers aged less than 18 years, they think they have white skin 
more important than being happy. The above is not much different from the results of the research by Fidalgo \& Bhakta (2018) which says that in America the standard of beauty can be seen from the ideal body shape and perfect faces such as a straight nose, smooth lips, a face without acne and a slim body.

Based on the survey, shows that many teenagers today want to look beautiful. Although the women's emancipation movement is widely discussed, women's subconscious is still controlled by feelings about their physical condition, namely the obsession with beauty (Wolf, in Rizkiyah \& Apsari, 2019). So it is not surprising that beauty is currently so revered, especially by women, and is willing to do everything possible to fulfill the dream of getting beauty (Meliana, 2006). In addition, Arsitowati (2017) says that current beauty standards have an impact on women spending their precious time covering or changing body parts that are considered less attractive. Therefore, certain appearance standards are applied can cause pressure for adolescence (Kholmogorova, Tarhanova \& Shaligina, 2017). Thus, dissatisfaction with the body is one of the causes of stress in adolescents (Wardani, Huriyati, Tyas \& Hastuti, 2015). A survey conducted by Anna (Kompas.com, 2019) stated that as many as 3 out of 10 teenagers said there was pressure to always look attractive and also have to be able to adapt socially to be one of the causes of depression. In addition, research by Dianovinina (2018) stated that $8 \%$ of the sample experienced depression and $28 \%$ experienced potential depression due to dissatisfaction with appearance.

Depression is an emotional condition characterized by the emergence of deep sadness, feeling insignificant, withdrawing from other people and the environment, difficulty sleeping, loss of appetite, and pleasure in usual activities (Davidson, et al, 2006). Several studies have shown that satisfaction with the body has a relationship with depressive symptoms. according to research conducted by Hamilton (2008) who said that their relationship and satisfaction appearance areas of the body against the depression, when the perception of the body decreases the symptoms of depression increased. In addition, factors that can affect depression are social support such as support from family and closest people (Wahyuni, Murwati \& Supiati, 2014).

Social support, according to Wang (in Qian \& Peng, 2014) is concerned or help from others that can be felt, noticed, or accepted by someone. The results of related research, social support with depression, stated by Sukma \& Panjaitan (2018) stated that social support has a relationship with depressed levels. Teo, Choi \& Valestine (2013) stated that the quality of social relationships is a major risk factor for major depression. In addition to social support which is an influence on depression, other factors such as self-esteem can affect depression. As stated by Dobson, (in Qahtani, 2017) Depression can be influenced by cognitive factors such as low self-esteem and pessimism. So based on this sentence self-esteem can be a factor in the emergence of depression.

Self-esteem is one of the more specific components of self-concept, which involves an element of evaluation or self-assessment (Robinson, 1991). Fitriah \& Hariyono (2019) stated that the higher the level of self-esteem, the lower the level of depression, and vice versa, the lower the self- 
esteem, the higher the level of depression. Manna, Falgares, Ingolia, Como \& Santis (2016) stated that low self-esteem affects symptoms of depression and anxiety.

Based on the explanation of the theory and the background that has been put forward, according to the researcher's assumption that the standard of adolescent desire to look attractive such as white skin, smooth face, and slim body can create pressure that tends to have an impact on depression tendencies. From the results of the theoretical study above, the factors that influence depression are social support and self-esteem.

\section{RESEARCH METHODS}

The population in this study were adolescent girls aged 14-18 years, who crave attractive appearance (white skin, ideal body) and perform self-care for at least 3 months. While the sample in this study is targeted at a minimum of 50 people based on several characteristics. The sampling technique used in this study is non-probability sampling, purposive sampling in which the determination of the sample is carried out with certain considerations.

Data collection in this study used quantitative research methods by distributing questionnaires. The questionnaires distributed consisted of the Beck depression scale (BDI-II), the social support scale, and the self-esteem scale.

Based on the research objectives mentioned earlier, namely to examine the effect of social support and self-esteem on the level of depression in adolescent girls.So, the technique used in testing the hypothesis is multiple regression techniques with the help of the SPSS Ver program. 21 for Windows.

\section{RESULT}

\subsection{Social Support And Self-Esteem Against Depression Tendency}

Based on data processing, the significance coefficient value is $0.000(\mathrm{p} \leq 0.01)$. So the hypothesis obtained is that there is a very significant influence of social support and self-esteem on the tendency of depression in adolescent girls. Based on the R Square obtained by $0.386(38.6 \%)$ it shows that the variables of social support and self-esteem contribute equally to the depression variable.

\begin{tabular}{|lcccccc|}
\hline \multicolumn{7}{c|}{ ANOVA $^{\text {a }}$} \\
1 & Rodel & Sum of Squares & df & Mean Square & F & Sig. \\
& Residual & 4002.633 & 107 & 37.408 & 33.586 & $.000^{\text {b }}$ \\
& Total & 6515.418 & 109 & & \\
a. Dependent Variable: Depresi \\
b. Predictors: (Constant), Harga_diri, Dukungan_Sosial
\end{tabular}




\subsection{Social Support Against Depression Tendency}

Based on data processing, the significance coefficient value was $0.021(\mathrm{p} \leq 0.05)$. In other words, the hypothesis obtained is that there is a very significant effect of social support on the tendency of depression in adolescent girls. Based on the R Square obtained by 0.049 $(4.9 \%)$ shows that the social support variable influences depression.

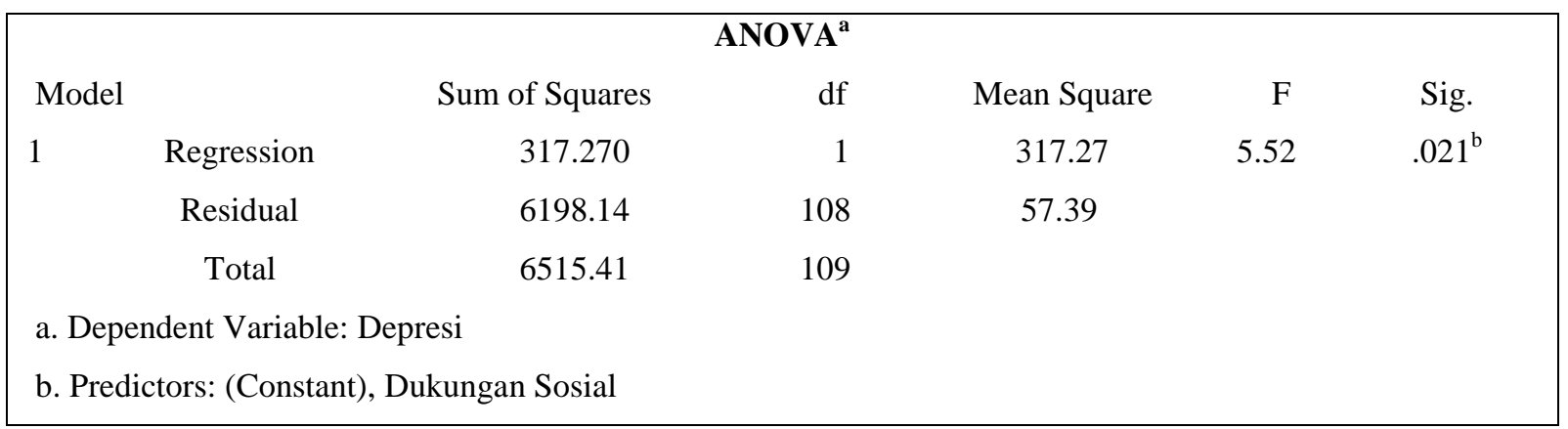

\subsection{Self-Esteem Against Depression Tendency}

Based on data processing, the significance coefficient value is $0.000(\mathrm{p} \leq 0.01)$. So the hypothesis obtained is that there is a very significant influence of self-esteem on the tendency of depression in adolescent girls. Based on the R Square obtained by 0.376 (37.6\%), namely the variable self-esteem influences the tendency of depression.

\begin{tabular}{|lcccccr|}
\hline \multicolumn{7}{|c|}{ ANOVA $^{\text {a }}$} \\
1 & & Sum of Squares & df & Mean Square & F & Sig. \\
& Regression & 2488.106 & 1 & 2488.106 & 66.723 & $.000^{\text {b }}$ \\
& Residual & 4027.312 & 108 & 37.290 & & \\
& Total & 6515.418 & 109 & & & \\
a. Dependent Variable: Depresi & & & \\
b. Predictors: (Constant), Harga diri & & & \\
\hline
\end{tabular}

\section{DISCUSSION}

The results above show that social support and self-esteem have a simultaneous influence on the tendency of depression in adolescents. So that the results of the first hypothesis are accepted as significant coefficient results of $0.000(\mathrm{P} \leq 0.01)$ with an $\mathrm{R}$ square value of 0.386 . This shows that there is an effect of social support and self-esteem together with the tendency of depression in adolescent girls by $38.6 \%$. This shows that the tendency of depression can be influenced by social support and self-esteem. Where individuals who have social support and high self-esteem will reduce the risk of developing depressive symptoms. 
Based on the results, the second hypothesis shows a significant coefficient of $0.021(\mathrm{p} \leq 0.05)$ with an R Square value of 0.49 (4.9\%). Based on these results, the second hypothesis of this study is accepted where there is an effect of social support on the tendency of depression by $4.9 \%$. Based on these results, it can be said that social support can affect depression. The higher the social support, the lower the depression, and the lower the social support, the higher the depression. Social support itself is an individual's belief in the availability of support provided by family, friends, and significant others who are there when the individual is in need (Zimet, Dahlem, Zimet \& Farlay, 1988). Some research results that can support by Wang, Cai, Qian \& Peng (2014) states that individuals with high levels of depression have low social support and conversely individuals with low depression scores have high social support. Another opinion by Alsubaie, et al (2019) said that social support from family and friends was a predictor of the emergence of depressive symptoms in individuals.

The third hypothesis in this study is the effect of self-esteem on the tendency of depression in adolescent girls. The results of the simple regression test show a significant value of $0.000(p \leq 0.01)$ which means that there is a significant effect of self-esteem on the tendency of depression in adolescent girls with an $\mathrm{R}$ square value of 0.376 (37.6\%). This means that self-esteem contributes $37.6 \%$ to the tendency of depression. Based on the results above, it is said that the higher the selfesteem, the lower the depression, and the lower the self-esteem, the higher the depression. Self-esteem is an individual's evaluation of himself positively or negatively and shows the level of belief as an individual who is capable, important, successful, and valuable (Coopersmith, in Burns 1993). Jayanthi \& Rajkumar (2014) states that low self-esteem is one of the risk factors for depression among adolescents. Individuals with low self-esteem have a high risk of depression and conversely, individuals with high self-esteem have a small risk of depression. Another study by Masselink, Roekel \& Oldehinkel (2018) stated that low self-esteem can make adolescents more prone to developing depressive symptoms.

Based on the results and research described above, it can be said that social support and selfesteem influence depression. Where when adolescence does not get support from the environment it will be the influence of depression. In addition, self-esteem influences depression, if adolescents have high self-esteem, the possibility of depression is low and vice versa.

Based on the results and discussion above, the researchers suggest interventions that can be used to help depression. Interventions that can be given are self-compassion interventions. Where selfcompassion itself is a form of healthy self-acceptance and an open attitude towards aspects of oneself and one's life that one does not like (Neff, Rude \& Kirkpatrick, 2007). The most basic aspects needed in forming self-compassion are self-kindness, common humanity, and mindfulness (Neff, 2003). Based on this statement, individuals need to accept their own strengths and weaknesses healthily. So that the intervention that can be given to avoid the emergence of depression is self-compassion intervention. reinforced by the results of research Souza (2020) states that there are significant selfcompassion to depression, where the higher self-compassion, the lower the depression that appears. 
Based on the research above, the researcher has limitations in preparing and conducting the research. here are flaws in the research conducted as a weakness in the assay, where there is some less appropriate item in pengartiannya. In addition, the respondent's criteria in this study still have shortcomings.

\section{SUMMARY}

Based on the results of the research that has been done, it shows that the hypothesis is accepted, namely that there is a simultaneous influence between social support and self-esteem on the tendency of depression in adolescent girls. This shows that the tendency of depression can be influenced by factors of social support and self-esteem. Other results show that social support influences depression. In addition, self-esteem influences the tendency to depression. So in this study, social support and self-esteem influence the tendency to depression.

The results of the empirical mean show that the respondents in this study have a level of depression in the low category. While social support in the medium category. Then, the self-esteem shows the moderate category as well. It can be seen that the respondents in this study did not all have problems with social support and self-esteem so that the level of depression in respondents was in a low category.

\section{References}

Alsubaie, M.M., Stain, H,J., Webster, L.A.D., Wadman, R. (2019). The role of sources of social support an depression and quality of life for university student. International journal of adolescence and touth, 0267-3943.

Arsitowati, W. H., (2017). Kecantikan wanita korea sebagai konsep kecantikan ideal dalam iklan new pond's white beauty: what our brand ambassadors are saying. HUMANIKA vol. 24 (2).

Berk, L.E. (2003). Child Development (6th ed.). Boston: Allyn And Bacon.

Davison, G.C., Neale, J.M., Kring, A.M. (2006). Psikologi abnormal-edisi ke-9. (Penerjemah: Noermalasari Fajar). PT. Raja Grafindo Persada, Jakarta.

Dianovinina, K. (2018). Depresi pada remaja. Jurnal Psikogenesis, Vol. 6, No.1.

Fidalgo, G \& Bhakta, K (2019). Negative effects of the standarts of feminine beauty in the united states. Latilude multidisciplinary research journal. Vol. 11.

Fitriah, A., Hariyono, D. S. (2019). Hubungan self-esteem terhadap kecenderungan depresi pada mahasiswa. Psyco Holistic. Vol. 1, No. 1.

Halmington, S. R. (2008). A relationship between perceived body image and depression: how college women see themselves may affect depression. Student journal of psychology science, 1(1), 13 20.

Ifdil, I., Denich, A. U., Ilyas, A. (2017). Hubungan body image dengan kepercayaan diri remaja putri. Jurnal kajian bimbingan dan konseling, 2 (3), 107-113.

Jayanthi., Rajkumar, R. (2014). Is low self-esteem a risk factor for depression among adolescence? An analytical study with interventional component. International journal of medical research 
and healty sciencs. Vol.3.

Manna, G., Falgares, G., Ingoglia, S., Como, M. R., Santis, S. D. (2016). The relationship between self-esteem, depression and anxiety: comparing vulnerability and scar model in the italian context. Mediterranaen journal of clinical psychology. Vol 4, No.3.

Masselink, M., Roekel, V. E., Oldehinke, A. J. (2018). Self esteem in early adolescenc as predictor of depression symptoms in late adolescence and early adulthood. Journal of Youth and Adolescence, 47(5),932-946.

Meliana, A. S. (2006). Menjelajah tubuh perempuan dan mitos kecantikan. Yogyakarta: LKIS.

Qahtani, A. (2017). Prevention of depression: a review of literature. Journal of Depression and Anxienty. Vol. 4 (4).

Rizkiyah, I., Apsari, N.C., Julina. (2019). Strategi koping perempuan terhadap standarisasi cantik masyarakat. Jurnal Perempuan, Agama Dan Jender, 18 (2).

Santrock, J. W. (2013). Adolescent. New York: McGraw-Hill Education

Sarwono, S.W. (2013). Psikologi remaja. Edisi revisi. Jakarta: PT Raya Grafindo Graham Ilmu.

Sukma, F.M., Panjaitan, R.U. (2018). Dukungan sosial dan hubungannya dengan tingkat depresi pada narapidana anak. Jurnal keperawatan. Vol. 6, No. 2

Teo, A. R., Choi, H., Valenstein, M. (2013). Social relantionships and depression: ten years followup from a nationally representative study. Vol. 8, 4-62396.

Wahyuni, S., Murwati., Supiati. (2014). Faktor internal dan eksternal yang mempengaruhi depresi postpartum. Jurnal ilmu kesehatan. Vol. 3

Wang, X., Cai, L., Qian J., Peng, J. (2014). Social support moderates stress effects on depression. International Journal of Mental Health Systems. 8:41.

Wang, X., Cai, L., Qian J., Peng, J. (2014). Social support moderates stress effects on depression. International Journal of Mental Health Systems. 8:41.

Wardani, D. A. K., Huriyati, E., Tyas, M., Hastuti, J. (2015). Obesitas, body image, dan stres pada mahasiswa di daerah istimewa jogjakarta. Jurnal gizi klinik indonesia. Vol. 11, No. 4.

Zimet, G. D., Dahlem, N. W., Zimet, G. D., \& Farley, G. K. (1998). The multidimensional scale of perceived social support, journal of personality assessment, 52 (1),34-41. 